\title{
Estrogenic induction of spermatogenesis in the hypogonadal (hpg) mouse: role of androgens
}

\author{
Helen Baines*, Margaret O Nwagwu*, Edwina C Furneaux, Jane Stewart ${ }^{1}$, Jeffrey B Kerr ${ }^{2}$, \\ Terry M Mayhew and Francis J P Ebling \\ School of Biomedical Sciences, University of Nottingham Medical School, Queen's Medical Centre, Nottingham \\ NG7 2UH, UK, ${ }^{1}$ AstraZeneca, Alderley Park, Cheshire, UK and ${ }^{2}$ Department of Anatomy and Cell Biology, \\ Monash University, Victoria 3800, Australia \\ Correspondence should be addressed to F Ebling; Email: fran.ebling@nottingham.ac.uk
}

$*(\mathrm{H}$ Baines and M O Nwagwu contributed equally to this work)

\begin{abstract}
Testicular development is arrested in the hypogonadal (hpg) mouse due to a congenital deficiency of hypothalamic gonadotropin-releasing hormone synthesis. Previous studies have demonstrated that chronic treatment of these mice with estradiol induces testicular maturation and qualitatively normal spermatogenesis, but it is not known whether these are direct effects via estrogen receptors expressed in the testis, or indirect actions via the pituitary gland. The aim of the current studies was to determine whether the actions of estradiol require the presence of androgens. Sensitive assays revealed that chronic estradiol treatment produced time-dependent increases in pituitary FSH production but no increases in pituitary LH or testicular testosterone content could be detected. As a functional test of androgen dependence, $h p g$ mice were treated for 70 days with estradiol plus Casodex (bicalutamide), an androgen receptor antagonist. Casodex treatment markedly attenuated both the estradiol-induced increase in testicular weight and the proliferation of the seminiferous epithelium, as revealed by morphometric analysis. However, it did not affect the estradiol-induced increase in pituitary FSH content, nor did it affect estradiolinduced increases in the weight of the seminal vesicles and epididymides. We conclude that increased FSH production is not sufficient to explain the increase in testicular development induced by estradiol in hpg mice; there is a requirement for functional androgen receptors for induction of testicular growth.
\end{abstract}

Reproduction (2005) 130 643-654

\section{Introduction}

Although follicle-stimulating hormone (FSH) and androgens are considered to be the principal regulators of Sertoli cell proliferation and function, and thus of spermatogenesis (Sharpe et al. 2003), it is becoming increasingly clear that estrogens also play a role in this process (see O'Donnell et al. 2001 for review). The mammalian testis expresses aromatase (Bourguiba et al. 2003), produces significant amounts of estradiol (Weniger 1993) and expresses both alpha and beta forms of the estrogen receptor (ER $\alpha$ and ERß) (Fisher et al. 1997, Saunders et al. 1998, Zhou et al. 2002). The progressive impairment of spermatogenesis observed in transgenic mice deficient in aromatase (Robertson et al. 1999) or ER $\alpha$ (Eddy et al. 1996, Hess et al. 1997) is thought to reflect predominantly a deficit in fluid reuptake in the efferent ducts of the testis, but the expression of ER in Leydig and Sertoli cells raises the possibility that estrogens also have actions within the testis itself. ER $\beta$ immunoreactivity has also been detected within the germ cell line in the rat and mouse testis (Saunders et al. 1998, Zhou et al. 2002) and ER $\alpha$ mRNA and immunoreactivity have been reported in human spermatozoa (Durkee et al. 1998). However, the demonstration that transgenic germ cells lacking ER $\alpha$ can be transplanted into a host testis depleted of native germ cells, and can then mature to produce viable offspring (Mahato et al. 2000), has focused attention on the actions of estradiol on the somatic components of the testis.

We have previously observed that treatment of hypogonadal (hpg) mice with low levels of estradiol causes increases in testicular weight that reflect maturation of the seminiferous epithelium and the production of spermatozoa (Ebling et al. 2000). The hpg mouse is an excellent animal model in which to investigate the mechanism of action of estrogens on spermatogenesis because it has arrested reproductive development without the need for surgical, endocrine, pharmacological or immunological intervention. This mouse line is infertile due to a congenital 
deficiency of hypothalamic gonadotropin-releasing hormone $(\mathrm{GnRH})$ synthesis leading to markedly reduced pituitary contents of luteinizing hormone $(\mathrm{LH})$ and $\mathrm{FSH}$ and undetectable or barely measurable serum gonadotropin levels (Cattanach et al. 1977, Charlton et al. 1983). Consequently, the testes fail to undergo normal postnatal development and, at an adult age, hpg testicular androgen production is barely detectable (Sheffield \& O'Shaughnessy 1989, Scott et al. 1990). Treatment of hpg mice with androgen alone is sufficient to induce spermatogenesis and this occurs in the absence of detectable FSH concentrations (Singh et al. 1995). Conversely, treatment with recombinant human FSH can induce testicular development in hpg mice, reflecting increased proliferation of spermatogonia and increased spermatocyte numbers (Singh \& Handelsman 1996). However, in the absence of supplementary testosterone treatment, spermatogenesis was arrested at the spermatoctye stage, with little evidence of formation of round spermatids (Singh \& Handelsman 1996). In contrast to the limited effects of treatment of hpg mice with FSH alone (Singh \& Handelsman 1996), our initial studies have shown qualitatively normal spermatogenesis after treatment with estradiol. The overall aim of the current study was to determine whether this might reflect actions of estradiol other than via pituitary release of FSH and, given the evidence for an absolute requirement for androgen in completion of spermatogenesis in the hpg mouse (Singh \& Handelsman 1996), we specifically investigated whether the actions of estradiol are androgen-dependent.

The main experimental approach was to determine whether concurrent treatment with Casodex (bicalutamide), a peripherally selective androgen receptor antagonist (Furr et al. 1987), could block the stimulatory actions of estradiol treatment in hpg mice. Casodex has been shown to induce subtle deficits in spermatogenesis in adult rats, for example, a reduction of germ cell numbers during stage VII of spermatogenesis (Chandolia et al. $1991 a, b)$. We also determined whether estradiol treatments that stimulate spermatogenesis could increase pituitary LH production, since our initial studies had only investigated effects on FSH release, and whether estradiol treatment could increase intratesticular androgen levels. Our initial studies in hpg mice did not detect increases in serum androgen concentrations (Ebling et al. 2000) but we predicted that, if the stimulatory action of estradiol was androgen-dependent, then small increases in intratesticular levels of androgen might occur after estradiol treatment. Finally, we determined whether the effects of estradiol could be blocked by concurrent treatment with Faslodex (ICl 182,780), an estrogen receptor antagonist (Wakeling \& Bowler 1992). This part of the study was carried out for two reasons: first as a positive control, to confirm that an infrequent administration regime with an antagonist could block the effect of estradiol delivered continuously by subcutaneous silastic implant. Secondly, the stimulatory effects of estradiol on spermatogenesis in hpg mice were so unexpected and paradoxical that we wished to confirm that the action was genuinely via the known genomic estrogen receptors, rather than an interaction of estradiol with other cellular mechanisms.

\section{Materials and Methods}

\section{Animals}

All studies were conducted using $\mathrm{C} 3 \mathrm{H} \mathrm{hpg}$ mice from a breeding colony at the Biomedical Sciences Unit (BMSU), University of Nottingham, originally derived from a stock procured from Jackson Laboratories, Inc. (Bar Harbor, ME, USA). The mice were aged between 21 and 29 weeks old at the start of the study and were housed with their male littermates. The temperature was maintained between 20 and $25^{\circ} \mathrm{C}$ in a $12 \mathrm{~h}$ light: $12 \mathrm{~h}$ darkness photoperiod, with food available ad libitum. All animal procedures were approved by the University of Nottingham Local Ethical Review Committee and were carried out in accordance with the Animals Scientific Procedures Act (UK) 1986 (project licence PPL 40/2372). Laboratory Science Animal Association (LASA) guidelines were followed for administration of substances (Morton et al. 2001). hpg males were identified by their unequivocal phenotype consisting of a micropenis and a shorter anogenital distance. The wildtype littermates are a combination of both homozygous $(+/+)$ and heterozygous $(+/ h p g)$ genotypes as such mice are phenotypically identical.

\section{Chronic estradiol treatments}

Estradiol implants were made by packing $10 \mathrm{~mm}$ crystalline $17 \beta$-estradiol (Sigma) mixed $1: 50(2 \%)$ by weight with cholesterol into silastic tubing $(1.59 \mathrm{~mm}$ i.d., $3.18 \mathrm{~mm}$ o.d.; Osteotec, Christchurch, Dorset, UK) plugged at either end with silicone medical adhesive (Osteotec). After the adhesive had been allowed to cure for at least $24 \mathrm{~h}$ at room temperature, implants were washed with $70 \%$ ethanol. They were then incubated in saline for $24 \mathrm{~h}$ before implantation, so that release rates would be stabilized by the time the implants were placed under the skin (Ebling et al. 2000). A single implant was placed subcutaneously into the flank under general anesthesia (ketamine $0.4 \mathrm{mg} / \mathrm{kg}$ and medetomidine $2 \mathrm{mg} / \mathrm{kg}$, i.p.; Dodge Animal Health, Southampton, UK). Anesthesia was reversed with $1 \mathrm{mg} / \mathrm{kg}$ atipamezole (Antisedan, Pfizer Animal Health, Sandwich, Kent, UK), and mice were treated post-operatively with $5 \mathrm{mg} / \mathrm{kg}$ carprofen, a non-steroidal anti-inflammatory analgesic (Rimadyl; Pfizer). These $2 \%$ estradiol implants maintain serum estradiol concentrations of approximately $40 \mathrm{pg} / \mathrm{ml}$ in adult female or male hpg mice, as measured 12 or 35 days after implantation respectively (Ebling et al. 2000). Vom Saal et al. (1997) reported estradiol levels of $94 \mathrm{pg} / \mathrm{ml}$ in fetal male mice, and Bianco et al. (2002) reported circulating estradiol concentrations of $14 \mathrm{pg} / \mathrm{ml}$ in adult male mice as compared with $19 \mathrm{pg} / \mathrm{ml}$ in $h p g$ male mice. Thus, the 
levels of estradiol produced by $2 \%$ estradiol implants are two- to three-fold higher that those found in normal adult male mice, but lower than those found in fetal male mice, and much lower than the 'supraphysiological' serum estradiol levels found in transgenic mice overexpressing human aromatase $(\sim 150 \mathrm{pg} / \mathrm{ml}$; Li et al. 2001). Moreover, the serum estradiol levels produced by our implants are much lower than those found in rete testis fluid of the adult rat $(\sim 250 \mathrm{pg} / \mathrm{ml}$; Free \& Jaffe 1979).

\section{Chronic hormone antagonist treatments}

Casodex and Faslodex were kindly donated by AstraZeneca Pharmaceuticals (Safety Assessment UK, Alderley Park, Macclesfield, Cheshire, UK). Doses of Faslodex (fulvestrant or $\mathrm{ICl} 182,780$, long-acting intramuscular formulation) were chosen on advice from AstraZeneca Pharmaceuticals. Administration of $250 \mathrm{mg} / \mathrm{kg}$ subcutaneously every 30 days to the mouse is known to cause expected anti-estrogenic changes in the male and female reproductive tract. Pharmacokinetic studies in the mouse conducted by AstraZeneca confirm that circulating levels of ICI 182,780 are detected 30 days post dose consistent with a slow release of $\mathrm{ICl} 182,780$ from the long-acting formulation. There is some accumulation on repeat dosing every 30 days. Thus, administration of $250 \mathrm{mg}$ Faslodex/kg every 3 weeks to the $h p g$ mouse would be expected to cause estrogen receptor blockade throughout the administration period.

Doses of Casodex (bicalutamide, ICI 176,334) were chosen following consultation with AstraZeneca Pharmaceuticals. Based on studies in mice carried out by AstraZeneca, administration of $5 \mathrm{mg} / \mathrm{kg} /$ day orally for 3 months or more is known to cause atropy of the prostate and seminal vesicles. Administration of $75 \mathrm{mg} / \mathrm{kg} / \mathrm{day}$, although well tolerated, causes significant liver hyperplasia associated with hepatic P450 induction. The dose used for the current studies $(40 \mathrm{mg} / \mathrm{kg}$ three times a week) was chosen as an intermediate effective dose, consistent with extensive dose-response studies in the male rat (Luo et al. 1997) and studies in male mice (Skarda 2003).

\section{Experimental designs}

Study 1: effect of chronic estradiol treatment on pituitary gonadotropin content

hpg mice received either a $2 \%$ estradiol implant or an implant containing cholesterol only. Pituitary glands and testes were collected from subgroups treated with $2 \%$ estradiol after 1, 3, 6 and 17 weeks of treatment and from groups treated with cholesterol after 1 and 17 weeks of treatment ( $n=3-5$ per subgroup). Pituitary glands were stored at $-20^{\circ} \mathrm{C}$, then homogenized in $0.5 \mathrm{ml} 0.01 \mathrm{M}$ phosphate-buffered saline (PBS) prior to assay.
Study 2: pilot study to determine activity of Casodex and Faslodex in hpg mice

Wet uterus weight was recorded in adult female $h p g$ mice ( $n=5-7$ per group) that had been treated for 14 days with a silastic capsule containing $100 \%$ cholesterol or $2 \%$ estradiol in cholesterol, or a single injection of $250 \mathrm{mg} / \mathrm{kg}$ Faslodex s.c. or vehicle, or with Casodex in $0.5 \%$ Tween 20 solution (oral gavage of $40 \mathrm{mg} / \mathrm{kg}$, three times per week), or with both a $2 \%$ estradiol silastic implant and $250 \mathrm{mg} / \mathrm{kg}$ Faslodex s.c. Uterine weights were also determined for an age-matched group of wild-type females.

Study 3: effect of androgen-receptor blockade on estradiol-induced testis development

$15 \mathrm{hpg}$ mice received a $2 \%$ estradiol implant and subgroups ( $n=5$ each) were also treated with (i) Casodex in $0.5 \%$ Tween 20 solution as an oral gavage at a dose of $40 \mathrm{mg} / \mathrm{kg}$, three times per week; (ii) Faslodex, $250 \mathrm{mg} / \mathrm{kg}$, s.c., at three-week intervals; or (iii) an oral gavage of vehicle (0.5\% Tween 20 solution) three times per week. A further group of $h p g$ mice received no treatment $(n=5)$, and a final group $(n=5)$ of age-matched wild-type mice also received no treatment. After 70 days of treatment, a blood sample was collected by cardiac puncture under terminal sodium pentobarbitone anesthesia (Rhone Merieux, Harlow, Essex, UK) and mice were then killed by cervical dislocation. Their testes, epididymides and seminal vesicles were excised, trimmed of fat and connective tissue, blotted dry on tissue and weighed. Pituitary glands were removed and stored at $-20^{\circ} \mathrm{C}$ until homogenized in $0.5 \mathrm{ml} 0.01 \mathrm{M} \mathrm{PBS}$ for assay of gonadotropins. Testes were immersed for up to $24 \mathrm{~h}$ in Bouin's fixative, processed through graded alcohols and embedded in paraffin wax blocks. These were serially sectioned at $5 \mu \mathrm{m}$, the sections mounted upon gelatinized microscope slides and stained with hematoxylin and eosin.

\section{Study 4: effect of chronic estradiol treatment on testicular androgen concentrations}

Unfixed testes were collected from hpg mice implanted with cholesterol $(n=7)$ or estradiol $(n=18)$ for between 8 and 10 weeks that constituted control groups for other studies, and also from untreated age-matched wild-type males $(n=3)$. Testes were stored at $-20^{\circ} \mathrm{C}$. Immediately prior to assay, they were homogenized in $0.5 \mathrm{ml} 0.01 \mathrm{M}$ phosphate-buffered saline, then extracted twice with $2 \mathrm{ml}$ ether. After the solvent was dried down, the extract was resuspended in $1 \mathrm{ml}$ assay buffer.

\section{Morphometric analyses}

The primary morphometric aims were to estimate volumes of seminiferous tubules and seminiferous epithelium within testes. To this end, stereological estimates (Howard \& Reed 1998) were made on tissue images randomized for location and orientation by a multistage systematic 
random sampling design. For each testis, four sections were randomly chosen for analysis and six fields were selected per section. Fields were sampled as images captured on a Leica DM4000B brightfield microscope via OpenLab software (Improvision, Coventry, West Midlands, UK) and printed to a final magnification of $\times 1000$ with the aid of a stage micrometer scale as an external calibration standard. Volume fractions of testicular component were determined by randomly superimposing a transparent grid comprising 35 test points in a quadratic array. The total number of points landing on a given component (tubule, lumen, epithelium), divided by the total number of points landing on the testis sections, determined the volume fraction. The absolute volume of each component per testis was estimated subsequently from the product of the volume fraction and the processed testicular volume. In order to assess whether changes in tubule volume were attributable to changes in calibre or total length, mean diameters of seminiferous tubules were measured after selecting tubules using an unbiased counting frame (Howard \& Reed 1998). In the case of elliptical profiles, the short axis was measured. To give an indication of the degree of germ cell development, each of the 24 fields per testis collected for stereological analysis was also scored by an observer blind to the experimental treatment to indicate the most mature germ cell type present within the field.

\section{Hormone assays}

The pituitary gland extracts from study 1 were assayed in duplicate at two or more dilutions using previously validated heterologous radioimmunoassays based upon reagents obtained from the NIDDK (National Institute of Diabetes and Digestive and Kidney Diseases) $\mathrm{NIH}$, Bethesda, MD, USA. The iodination of the tracer preparations (rat FSH, AFP-11454B and rat LH, AFP-11536B) was carried out using the Chloramine-T method. Pituitary extracts and serum samples from wild-type $\mathrm{C} 3 \mathrm{H}$ mice diluted in parallel to the standard curve and gonadotropin concentrations were expressed relative to these standards (mouse FSH, AFP-5308D, mouse LH, AFP-5306A). In study 2, FSH and LH contents in pituitary gland extracts were compared using a rat FSH immunoradiometric kit (AH R004, Biocodehycel, Liege, Belgium) and a rat LH RIA kit respectively (AH R002, Biocodehycel). Pituitary extracts from wild-type and hpg mice diluted in parallel with the rat FSH standard; the limit of detection was $1.5 \mathrm{ng} / \mathrm{ml}$ (7.5 ng/pituitary when $100 \mu$ l extract assayed). All samples were measured in a single assay. The LH assay is a highly sensitive assay (limit of detection $0.12 \mathrm{ng} / \mathrm{ml}$ for a $100 \mu \mathrm{l}$ sample, i.e. $0.6 \mathrm{ng} /$ pituitary) but, as murine extracts did not dilute in parallel with the rat standards, all experimental samples were compared at the same dilution in a single assay. The values expressed for pituitary content should be considered as relative values rather than absolute values due to this partial cross-reactivity of murine LH with the anti-rat $\mathrm{LH}$ antiserum.
Intratesticular androgen was measured using a highly sensitive solid phase ELISA (DRG1559 kit; Immunodiagnostic Systems Ltd, Boldon, Tyne \& Wear UK). The limit of detection for a $100 \mu \mathrm{l}$ sample of reconstituted extract was $10 \mathrm{pg} / \mathrm{tube}$ which equates to $0.1 \mathrm{ng} /$ testis. All samples were extracted in a single batch and assayed in the same ELISA, and are not corrected for the efficiency of the extraction process. This assay is highly specific for testosterone; crossreactivity with other androgens is less than $0.9 \%$.

\section{Statistical analysis}

Data are presented as group mean values \pm S.E. A oneway ANOVA (Statview, Calabas, CA, USA or Prism 2.01, GraphPad Software, San Diego, CA, USA) was used initially to determine whether there were significant overall effects of the various treatments on organ weights, testis morphometry and hormone values. Subsequently, individual groups were compared with a defined control group using Dunnett's procedure for post-hoc comparisons, or multiple comparisons between groups were made using Tukey's post-hoc tests. For histometric studies on the predominant germ cell types in random microscopical fields, numerical frequency distributions were pooled across animals within each group. Distributions in treated and untreated hypogonadal groups were then compared using a $4 \times 3$ contingency table design and a chi-squared analysis where 4 is the number of groups and 3 is the number of germ cell types (spermatocytes, round spermatids and elongating spermatids). For statistical purposes, hormone values below the assay limit of detection were assigned the limit value in analyses. $P$ values $<0.05$ were considered statistically significant.

\section{Results}

\section{Study 1: effect of chronic estradiol treatment on pituitary gonadotropin content}

Estradiol treatment induced a significant increase in testis weight in hpg mice after one week of treatment as compared with untreated or cholesterol-treated control hpg mice $(P<0.05 ;$ Fig. 1 , lower panel). Longer durations of estradiol treatment progressively increased testis weight in hpg mice $(P<0.001)$. Pituitary FSH content was significantly increased after 3 and 6 weeks of estradiol treatment $(P<0.05)$, and was further increased after 17 weeks of treatment $(P<0.001$; Fig. 1 , upper panel). There was no significant effect of estradiol treatment on pituitary $\mathrm{LH}$ content in male hpg mice (Fig. 1, middle panel).

\section{Study 2: pilot study to determine activity of Casodex and Faslodex in hpg mice}

Estradiol treatment for 14 days induced a significant increase in uterine weight in female $h p g$ mice $(P<0.001)$ such that the mean uterine weight reached $63 \%$ of that in age-matched wild-type females (Fig. 2). The single 


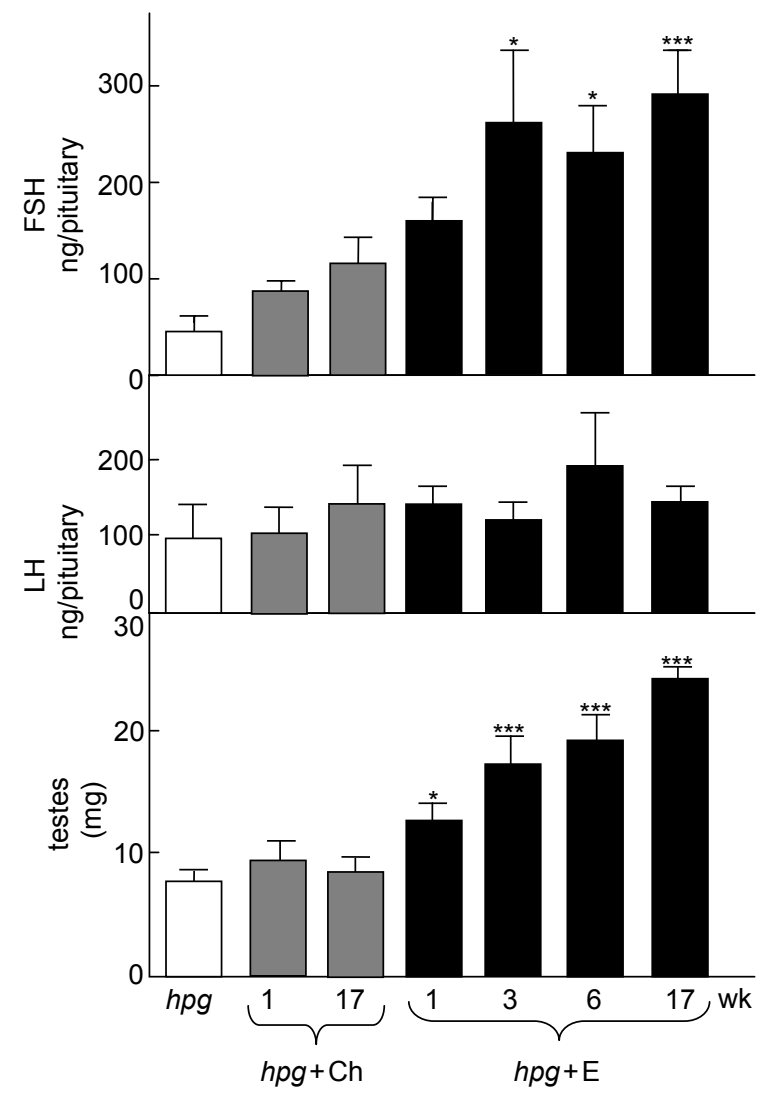

Figure 1 Study 1: pituitary content of FSH (top panel) and LH (middle panel), and wet weight of paired testes (bottom panel) in adult $h p g$ mice receiving no treatment (open bars), a subcutaneous implant containing cholesterol (Ch; shaded bars) or implants containing $2 \%$ estradiol in cholesterol ( $\mathrm{E}$; solid bars). Mice were treated for the number of weeks $(w k)$ indicated. Values are group means \pm S.E., $n=3-5$ per group. $* P<0.05, * * * P<0.001$ compared with cholesterol-treated control groups.

treatment of $250 \mathrm{mg} / \mathrm{kg}$ Faslodex s.c. was sufficient to attenuate (by 66\%) the stimulatory action of the estradiol implant treatment $(P<0.05)$. No estrogen-agonist properties (i.e. stimulatory effects on uterine weight) of Faslodex or Casodex were observed in the female hpg mice (Fig. 2).

\section{Study 3: effect of androgen-receptor blockade on estradiol-induced testis and accessory gland development}

Estradiol treatment for 10 weeks induced significant increases in the weight of the testes $(P<0.001)$, epididymides $(P<0.001)$ and seminal vesicles $(P<0.001)$ in hpg mice (Fig. 3). Testis and epididymal weights after estradiol treatment were five- to six-fold lower than those in age-matched wild-type mice, the weights of the seminal vesicles reached about $10 \%$ of those observed in wildtype controls (Fig. 3). Concurrent Casodex treatment significantly and substantially attenuated the estradiolinduced increase in testis weight $(P<0.001$; Fig. 3, top panel), although testis weights remained above those of

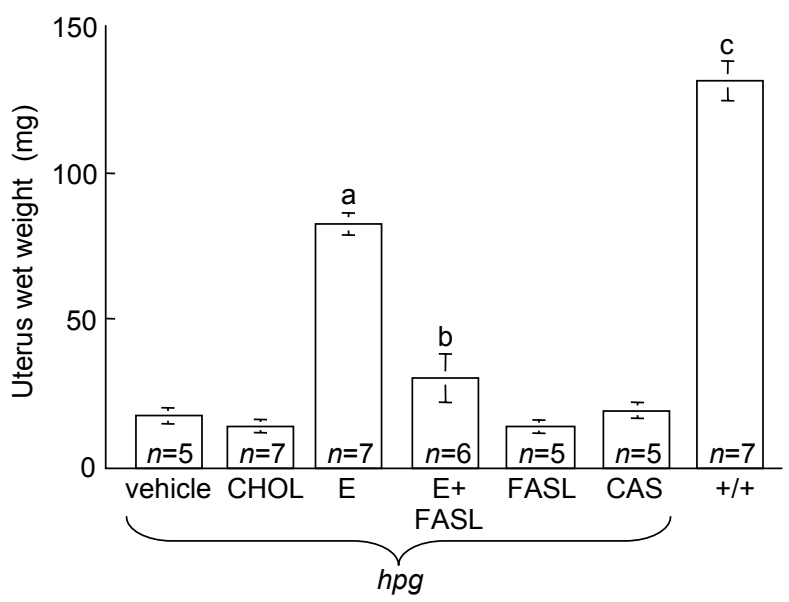

Figure 2 Study 2: wet weight of the uterus in female hpg mice that were treated for 14 days with a silastic capsule containing $100 \%$ cholesterol $(\mathrm{CHOL})$ or $2 \%$ estradiol in cholesterol $(\mathrm{E})$, or a single injection of $250 \mathrm{mg} / \mathrm{kg}$ Faslodex s.c. (FASL), or vehicle, or with Casodex (CAS; oral gavage of $40 \mathrm{mg} / \mathrm{kg}, 3 \times$ per week), or with both a $2 \%$ estradiol silastic implant and $250 \mathrm{mg} / \mathrm{kg}$ Faslodex s.c. (E + FASL). Uterine weights were also determined for an age-matched group of wild-type females $(+/+)$. Values are group means \pm S.E., group size as indicated. ${ }^{a} P<0.001$ compared with $\mathrm{CHOL}$ and $\mathrm{E}+\mathrm{FASL}$ groups, ${ }^{\mathrm{b}} P<0.05$ compared with $\mathrm{CHOL}$ group, ${ }^{\mathrm{c}} \mathrm{P}<0.001$ compared with all other groups.

the untreated hpg group $(P<0.05)$. Casodex treatment did not affect the estradiol-induced increases in the weight of the epididymides or seminal vesicles (Fig. 3, middle and bottom panels). Concurrent Faslodex treatment significantly $(P<0.001)$ attenuated the estradiol-induced increases in the weight of all three organs (Fig. 3).

Morphometric analysis confirmed that the increase in testis weight after estradiol treatment was a reflection of development of the seminiferous epithelium, resulting in significant increases in the volume and diameter of the seminiferous tubules $(P<0.001$; Table 1 , Fig. 4). Results further confirmed that differences in tubule volume were attributable solely to changes in epithelial height (and, hence, tubule diameter) and were not accompanied by changes in total tubule length. Round or elongating spermatids were present in all tubules examined after estradiol treatment (Table 2, Fig. 4). The seminiferous epithelium and total tubule volumes and lengths were nevertheless not as great as in age-matched wild-type mice (Table 1, Fig. 4). Casodex treatment significantly attenuated the effects of estradiol on the seminiferous epithelium $(P<0.001)$, tubule diameter and volume (both $P<0.01$; Table 1) but did not influence length. Round or elongating spermatids were only observed in a small proportion of tubules (Table 2, Fig. 4), very similar to the tubules in untreated hpg mice of a comparable age. Concurrent Faslodex treatment also significantly blocked the estradiolinduced increase in the seminiferous epithelium and total tubule volume (Table 1) and impaired the maturation of germ cells to the spermatid stages (Table 2, Fig. 4). 


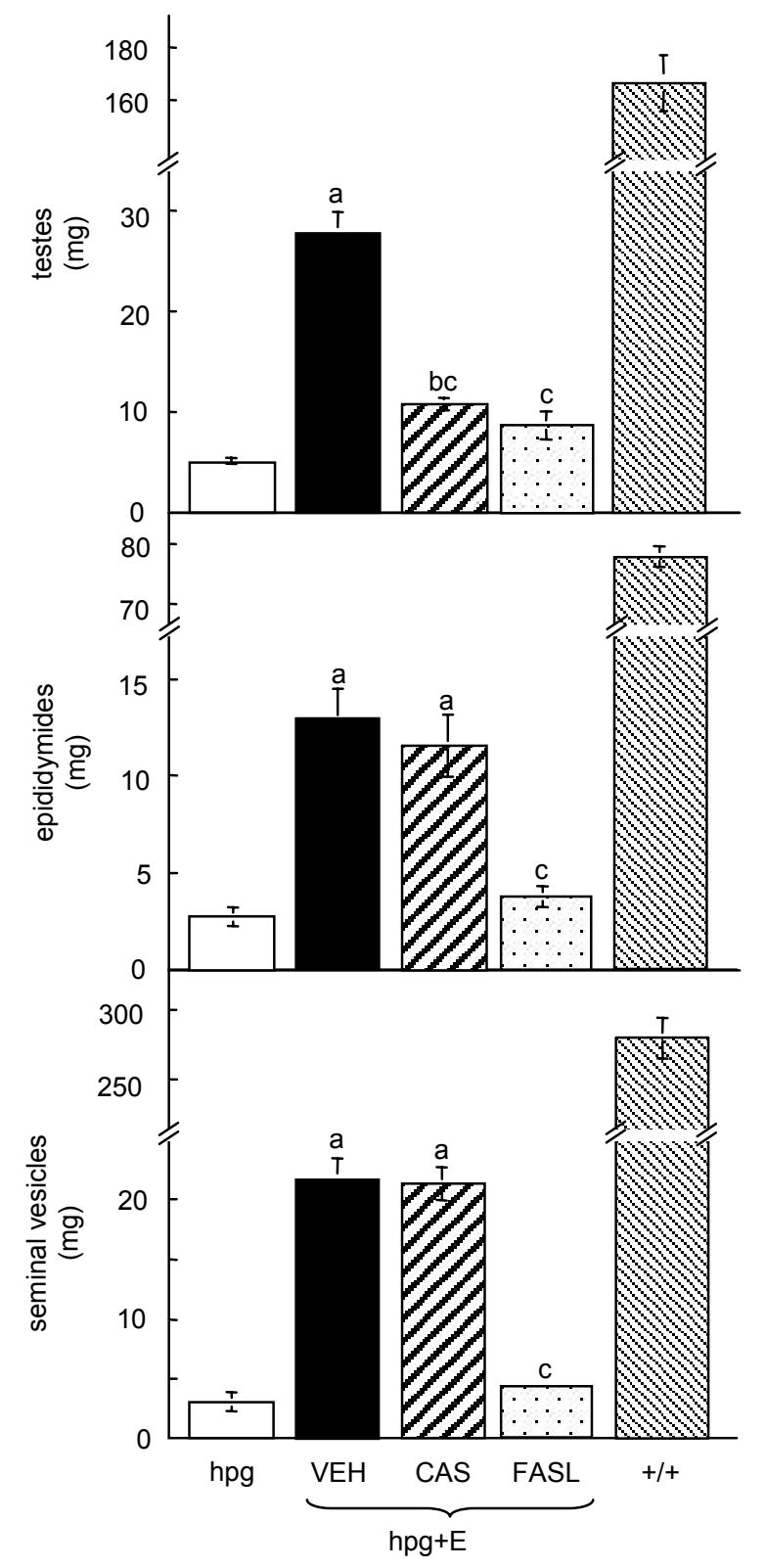

Figure 3 Study 3: wet weight of the paired testes (top panel), epididymides (middle panel) and seminal vesicles (bottom panel) in adult hpg mice receiving no treatment (open bars), or receiving a subcutaneous implant containing $2 \%$ estradiol (E) for 10 weeks plus $3 \times$ per week oral gavage of vehicle (VEH; solid bars) or Casodex at $40 \mathrm{mg} / \mathrm{kg}$ (CAS; wide-spaced hatched bars), or receiving subcutaneous injections of Faslodex $(250 \mathrm{mg} / \mathrm{kg}$ ) on days 0, 21, 42 and 63 of the trial (FASL; stippled bars). Paired organ weights for an agedmatched group of untreated wild-type $\mathrm{C} 3 \mathrm{H}$ mice are depicted on the right $(+/+)$. Values are group means \pm S.E., $n=5$ per group.

${ }^{\mathrm{a}} P<0.001$ and ${ }^{\mathrm{b}} P<0.05$ compared with untreated $h p g$ group,

${ }^{\mathrm{c}} P<0.001$ compared with estradiol-treated $h p g+\mathrm{VEH}$ group.

Contingency table analysis of germ cell development in hypogonadal groups (Table 2) confirmed that there were significant between-group differences (chi-squared 263.1 for 6 degrees of freedom, $P<0.001)$. These were attributable exclusively to estradiol treatment, which reduced the incidence of spermatocytes and increased the incidence of spermatid types in the seminiferous epithelium. Neither concurrent Casodex nor concurrent Faslodex had significant impacts on the distribution of germ cell types compared to untreated hpg mice. However, both treatments compromised the enhanced maturation of spermatids seen in estradiol-treated mice.

Estradiol treatment significantly $(P<0.01)$ increased pituitary FSH content (Fig. 5, upper panel). Concurrent Casodex treatment did not affect the estradiol-induced increase in FSH content, whereas Faslodex treatment significantly attenuated the effect of estradiol $(\mathrm{P}<0.05)$ (Fig. 5). No significant effects of treatment were observed on pituitary LH content (Fig. 5, lower panel).

\section{Study 4: effect of chronic estradiol treatment on testicular androgen concentrations}

Testicular testosterone content was low or below the limit of detection (in 3 of 7 testes) in hpg mice treated with cholesterol implants (range $0.10-0.38 \mathrm{ng} /$ testis). Estradiol treatment had no significant effect on mean testicular testosterone content (Fig. 6), 10 of 18 values were below the limit of detection (range $0.10-0.55 \mathrm{ng} /$ testis). The mean testosterone content in testes of hpg mice was approximately $0.6 \%$ of that in testes of wild-type $\mathrm{C} 3 \mathrm{H}$ mice of a similar age (Fig. 6).

\section{Discussion}

The current studies confirm and extend our initial observations that estradiol treatment promotes spermatogenesis in hpg mice. Using two different immunoassay systems, we have confirmed that this action of estradiol is associated with a progressive increase in pituitary FSH content. This is consistent with the estradiol-induced increases in serum FSH that we previously observed in male hpg mice (Ebling et al. 2000), and is also consistent with a previous report that estradiol benzoate treatment significantly increased pituitary FSH content and plasma FSH concentrations in adult male hpg mice (Stanley et al. 1988). In contrast, using two different immunoassay systems, we have not detected any increase in pituitary LH content following estradiol treatment, although there are detectable (but extremely low) levels of immunoreactive LH in the pituitary gland of $h p g$ mice. The presence of bioactive LH in the pituitary glands of male hpg mice, albeit at far lower levels than in wild-type mice, has long been established (Fink et al. 1983). The lack of effect of exogenous estradiol on pituitary LH content in hpg mice is also in accordance with the previous study in which estradiol benzoate treatment did not affect pituitary $\mathrm{LH}$ content in adult male hpg mice (Stanley et al. 1988). Consistent with the lack of estradiol-induced increase in pituitary LH content, we failed to observe any increase in testicular testosterone content after estradiol treatment. 
Table 1 Morphometric analyses of tests in study 3. Values are group means \pm S.E.

\begin{tabular}{|c|c|c|c|c|c|}
\hline & hpg & $h p g$ + E + VEH & $h p g+E+C A S$ & $h p g+E+F A S L$ & $+/+$ \\
\hline Number of animals & 5 & 5 & 5 & 5 & 5 \\
\hline Age (days) $)^{\mathrm{a}}$ & $205 \pm 1$ & $229 \pm 5$ & $244 \pm 9$ & $244 \pm 12$ & $202 \pm 6$ \\
\hline Body weight $(g)^{a}$ & $36.1 \pm 3.2$ & $27.0 \pm 1.9$ & $26.5 \pm 1.8$ & $26.4 \pm 1.4$ & $31.3 \pm 0.9$ \\
\hline Testis weight (mg) & $2.5 \pm 0.2$ & $13.7 \pm 1.0 *$ & $5.3 \pm 0.3 * *, \dagger$ & $4.3 \pm 0.7 \dagger$ & $85.2 \pm 3.9$ \\
\hline Tubule diameter $(\mu \mathrm{m})$ & $47 \pm 0.6$ & $106 \pm 6.4 *$ & $74 \pm 3.5+t$ & $62 \pm 2.0 \dagger$ & $178 \pm 0.9$ \\
\hline Tubule volume $(\mu \mathrm{l})$ & $1.7 \pm 0.3$ & $12.2 \pm 0.9 *$ & $4.1 \pm 0.2+\dagger$ & $3.9 \pm 0.7+\dagger$ & $70.4 \pm 2.7$ \\
\hline Tubule length (m) & $1.0 \pm 0.2$ & $1.5 \pm 0.3$ & $1.0 \pm 0.1$ & $1.3 \pm 0.2$ & $2.8 \pm 0.1$ \\
\hline Tubule (\% testis) & $77.1 \pm 1.1$ & $87.5 \pm 2.0 * *$ & $78.1 \pm 1.8+\dagger$ & $85.0 \pm 1.7$ & $81.7 \pm 1.8$ \\
\hline Seminiferous epithelium volume $(\mu \mathrm{l})$ & $1.7 \pm 0.3$ & $9.6 \pm 0.7 *$ & $4.1 \pm 0.2 \dagger$ & $3.7 \pm 0.6+$ & $52.2 \pm 2.7$ \\
\hline
\end{tabular}

${ }^{\mathrm{a}}$ Age at end of experiment; ${ }^{\mathrm{b}}$ Wet weight.

Superscripts indicate significant differences revealed by Tukey's tests after ANOVA: $* P<0.001$ and $* * P<0.05$ vs untreated hpg group; $+P<0.001$ and $++P<0.01$ vs $h p g+\mathrm{E}+\mathrm{VEH}$ group

E, estradiol; VEH, vehicle; CAS, casodex; FASL, faslodex; +/+, wild-type males.

Table 2 Germ cell development in study 3. Assessment of most advanced germ cell phenotype in testis sections used for morphometric analyses. Values are expressed as overall percentages, derived from analysis of 120 fields per group ( 5 mice $\times 24$ fields per testis).

\begin{tabular}{|c|c|c|c|c|c|}
\hline Most advanced phenotype & hpg & $h p g$ + E + VEH & $h p g+E+C A S$ & $h p g+E+F A S L$ & $+1+$ \\
\hline Spermatocytes & $77 \%$ & $0 \%$ & $82 \%$ & $78 \%$ & $0 \%$ \\
\hline Round spermatids & $13 \%$ & $44 \%$ & $8 \%$ & $5 \%$ & $0 \%$ \\
\hline Elongating spermatids & $10 \%$ & $56 \%$ & $11 \%$ & $17 \%$ & $100 \%$ \\
\hline
\end{tabular}

Differences between $h p g$ groups are significant (chi-squared 236.1 for 6 degrees of freedom, $P<0.001$ ) and focused exclusively on $h p g+E+$ VEH mice.

E, estradiol; VEH, vehicle; CAS, casodex; FASL, faslodex; +/+, wild-type males.

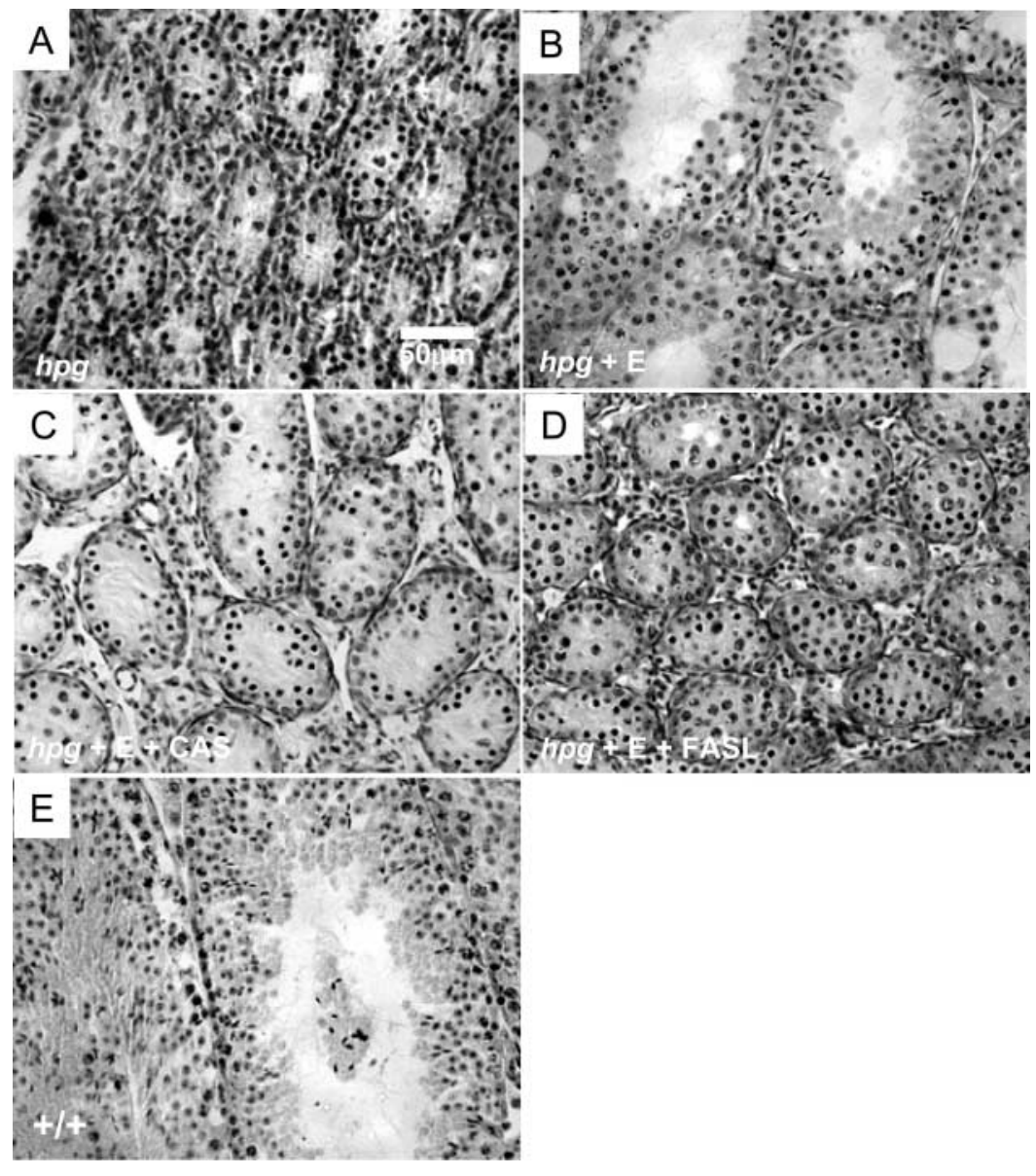

Figure 4 Study 3: representative examples of testicular histology. (A) Seminiferous cords in a testis from an untreated hpg mouse. (B, C, D) Cross-sections of tubules from $h p g$ mice receiving a $2 \%$ estradiol implant for 10 weeks and concurrently treated $3 \times$ per week with an oral gavage of vehicle (B) or Casodex at $40 \mathrm{mg} / \mathrm{kg}(\mathrm{C})$, or receiving subcutaneous injections of Faslodex $(250 \mathrm{mg} / \mathrm{kg})$ on days $0,21,42$ and 63 of the trial (D). (E) Seminiferous tubules from an age-matched wild-type litter mate. Note that estradiol treatment (B) stimulates development of the seminiferous epithelium, and that both the androgen receptor antagonist Casodex (C) and the estrogen receptor antagonist Faslodex (D) impair this action of estradiol. The $50 \mu \mathrm{m}$ scale bar in panel $\mathrm{A}(h p g)$ applies to all panels. 


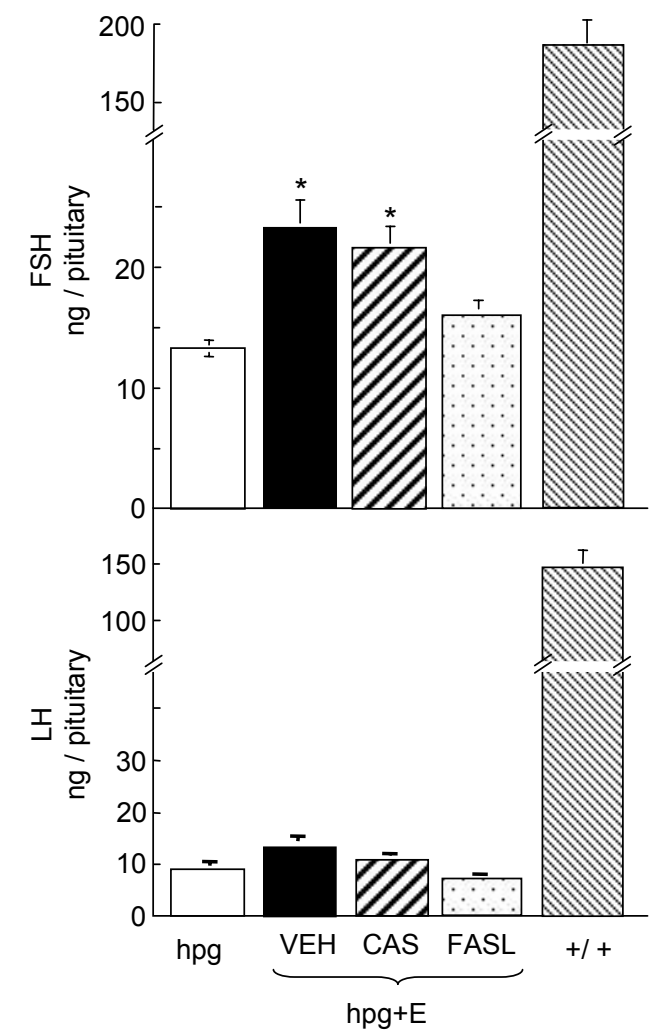

Figure 5 Study 3: pituitary FSH (top panel) and LH (bottom panel) content in adult $h p g$ mice receiving no treatment (open bars), or receiving a subcutaneous implant containing $2 \%$ estradiol (E) for 10 weeks plus $3 \times$ per week oral gavage of vehicle $(\mathrm{VEH}$; solid bars) or Casodex at $40 \mathrm{mg} / \mathrm{kg}$ (CAS; wide-spaced hatched bars), or receiving subcutaneous injections of Faslodex on days 0, 21, 42 and 63 of the trial (FASL; stippled bars). Values are group means \pm S.E., $n=5$ per group. $* P<0.01$ compared with untreated $h p g$ group. Values for aged-matched untreated wild-type $\mathrm{C} 3 \mathrm{H}$ mice are depicted on the right $(+/+)$.

Low testosterone concentrations were detectable in the majority of testes analyzed from hpg mice, as previously observed (Singh et al. 1995). This low level of androgen in the hpg testis is clearly of major significance in terms of the action of estradiol because the key finding of the current series of studies is that blockade of the androgen receptor with Casodex greatly attenuated the induction of spermatogenesis by estradiol. However, concurrent Casodex treatment did not block the stimulatory actions of estradiol on pituitary FSH production. The incomplete blockade of the estradiol-induced increase in testis weight could be taken as evidence that some actions of estradiol in the hpg male are independent of androgens, or could reflect a sub-maximal dose of the drug in this particular experimental paradigm. Moreover, we cannot fully exclude the possibility that Casodex has some partial agonist activity in hpg mice as there were not sufficient mice available to confirm that treatment with Casodex alone produced no effect on the testis. However, the pilot studies in female hpg mice did not reveal any estrogen-agonist

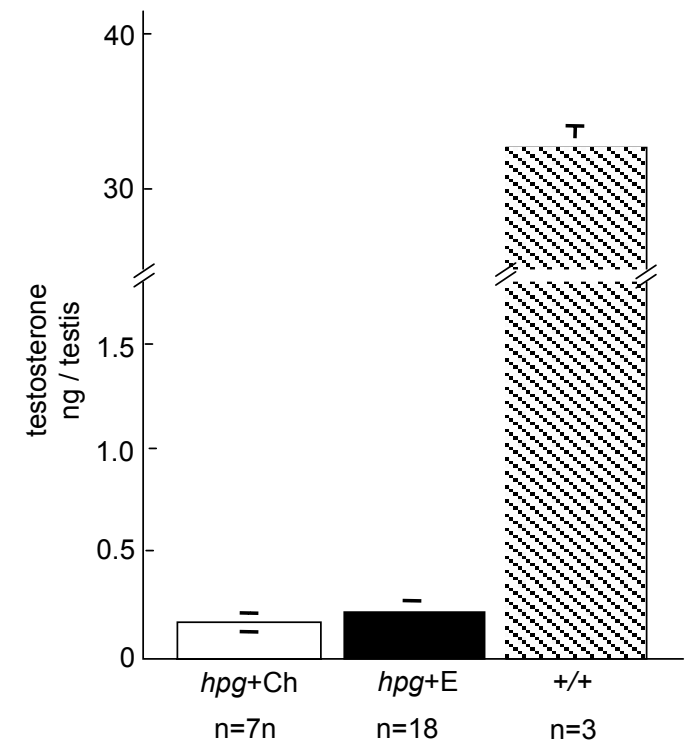

Figure 6 Study 4: testicular testosterone content in adult hpg mice receiving a subcutaneous implant containing cholesterol (Ch; open bar) or 2\% estradiol (E) for 8-10 weeks (solid bar) or in adult wildtype litter mates $(+/+$; hatched bar). Values are group means \pm S.E., $n$ as indicated.

activity of this compound, and no partial androgen-agonist properties of Casodex were reported in a previous study of its effects in intact and castrated C3H mice (Skarda 2003). We therefore conclude that, in the mouse, testosterone action is critical for the completion of spermatogenesis; FSH alone is not sufficient. Indeed, in a previous study in which hpg mice were treated with androgens alone, qualitatively normal spermatogenesis was induced despite an absence of detectable circulating $\mathrm{FSH}$ concentrations (Singh et al. 1995). Thus, in a qualitative sense, FSH is not even necessary for spermatogenesis in the mouse although, in a quantitative sense, it is extremely important because of its actions on Sertoli cell proliferation and function during the postnatal and pubertal periods (Johnston et al. 2004).

The current studies provide several insights into understanding how estradiol interacts with FSH and testosterone to regulate spermatogenesis. We have considered four hypotheses that are illustrated as models in Fig. 7. Models I and II consider actions of estradiol within the testis, since the presence of aromatase in the testis and direct measurements of estradiol production support the view that low levels of estradiol might be produced to act as a paracrine factor (see Carreau 2002 for review). The most direct hypothesis to explain how Casodex blocks the action of estradiol would be that estradiol acts upon Leydig cells to promote androgen production, which then acts upon the seminiferous tubules (Fig. 7, model I). In support of this model is the observation that in both rodents and primates, Leydig cells express ER $\alpha$ (Fisher et al. 1997, Pelletier \& El-Alfy 2000, Zhou et al. 2002), yet there has been no functional explanation for this 
I. E acts directly on Leydig cell

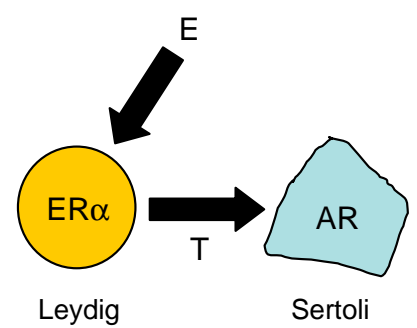

III. E stimulates $\mathrm{LH}$ release

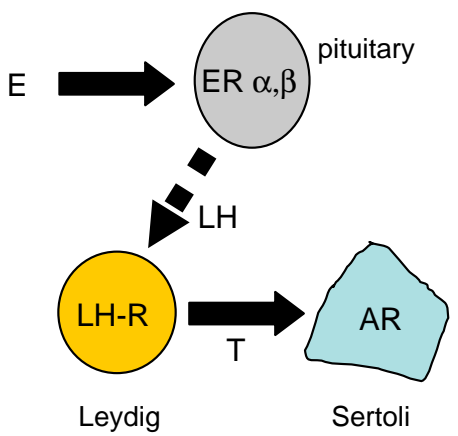

II. E acts directly on Sertoli cell

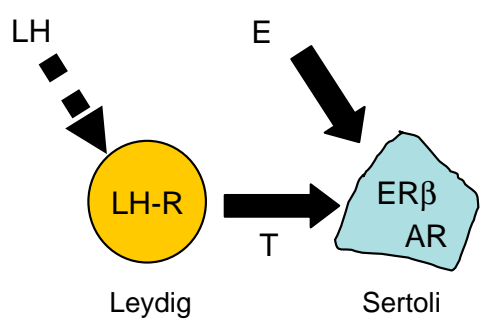

IV. E stimulates FSH-androgen synergism

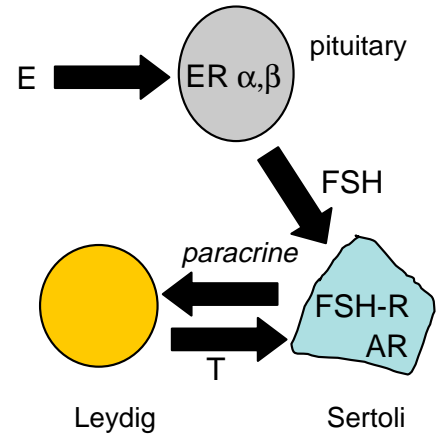

Figure 7 Schematic models that may explain estrogenic actions on testis development and function in the hpg mouse. Present results favor model IV or a composite model; see text for details. E, estrogen; T, testosterone; AR, androgen receptor; $\mathrm{ER} \alpha$, estrogen receptor alpha; $\mathrm{ER} \beta$, estrogen receptor beta; LH-R, luteinizing hormone receptor; FSH-R, follicle-stimulating hormone receptor. finding. The limitations of this model are that we were unable to detect any increase in testicular testosterone content after estradiol treatment and are unaware of any other functional evidence that estrogens can promote androgen production by Leydig cells. Indeed, the majority of evidence suggests that estradiol inhibits Leydig cell proliferation and steroidogenesis (see Abney 1999 for review).

A second 'paracrine' hypothesis (Fig. 7, model II) is that estradiol acts upon somatic cells within the seminiferous tubule, either Sertoli cells or perhaps peritubular cells as both have been reported to express ER $\beta$ (Saunders et al. 1998, van Pelt et al. 1999, Zhou et al. 2002), and that the actions of estradiol are to augment or synergize with those of testosterone. This model would not require that estradiol treatment increased either pituitary $\mathrm{LH}$ production or synthesis of testosterone by Leydig cells in the hpg males, as the basal testosterone levels measured may be sufficient to provide a low level of androgenic drive to the tubule with which estradiol can synergize. The major site of estradiol synthesis switches from the Sertoli cell prenatally to the Leydig cell postnatally, so it would seem very plausible that the physiological role of estradiol is as a paracrine signal from the Leydig cell to the tubule. However, when considering how the stimulatory action of estradiol in the hpg mouse can be blocked by an anti-androgen, model II is problematic. This is because the postnatal Sertoli cell only appears to express ER $\beta$, but there is no clear evidence for a physiological role of estradiol acting via
$\mathrm{ER} \beta$ in the testis, as transgenic mice lacking $\mathrm{ER} \beta$ reportedly show no deficits in fertility (Krege et al. 1998).

Models III and IV (Fig. 7) consider actions of estradiol within the pituitary gland, as our Western blot studies reveal the presence of both $E R \alpha$ and $E R \beta$ immunoreactivity of appropriate molecular weight in the pituitary gland of male hpg mice (Nwagwu et al. 2003). Moreover, in female mice, estradiol treatment is known to elicit daily 'ovulatory' surges of LH (model III) and FSH (model IV) the phenomenon of positive feedback (Murr et al. 1973, Bronson \& Vom Saal 1979). It might be hypothesized that due to incomplete postnatal masculinization, the male hpg mouse can also express such responses to estradiol treatment. Present studies confirm that estradiol treatment of male hpg mice increases FSH content, although no significant increase in pituitary LH content was observed after estradiol. Likewise, serum LH concentrations were undetectable in hpg mice (E C Furneaux \& F J P Ebling, unpublished data). Model III may seem unlikely given the failure to observe an increase in pituitary LH content after estradiol treatment. However, the slight possibility remains that serum LH levels were increased by estradiol but were still below the assay limits of detection.

Model IV (Fig. 7) is supported by a number of lines of evidence. The estradiol-induced rise in $\mathrm{FSH}$ has been observed in all studies that we have carried out in $h p g$ mice and the model predicts that this increase in FSH acts upon Sertoli cells by synergizing with the low level of testosterone produced by the Leydig cells. Indeed, in vitro 
studies in which Leydig and Sertoli cells were co-cultured suggest that FSH may augment the production of testosterone by Leydig cells via release of paracrine factors from Sertoli cells (Verhoeven \& Cailleau 1990). It should be noted that although the estradiol treatment produced approximately twofold increases in pituitary FSH content in male hpg mice, the resulting pituitary FSH content was still an order of magnitude less than that in wild-type male mice (Fig. 5). Circulating FSH concentrations were not measured in the current study, but our previous studies in hpg males using similar estradiol treatments revealed that serum FSH concentrations reached $30-40 \%$ of those found in wild-type males (Ebling et al. 2000). We were unable to detect any increase in testicular testosterone content (study 4) despite these increases in FSH, and a previous study in which hpg mice were directly treated with recombinant $\mathrm{FSH}$ also failed to detect increases in serum or testicular testosterone (Singh \& Handelsman 1996). However, model IV does not require that testosterone levels should increase, merely that a low level of testosterone should be present within the testis that will then permit the actions on the Sertoli cell of the increase in FSH that is induced by estradiol treatment.

Given that multiple cell phenotypes in the reproductive axis express estrogen receptors, one might expect multiple sites of action of estradiol, and thus the physiological effects of estradiol may only be understood via a combination of the proposed models. The common feature of models reflecting the current findings is the critical dependence on testosterone for induction of spermatogenesis; FSH alone cannot support spermatogenesis in mice. Similar conclusions have been reached in other studies in mice where FSH or testosterone signaling has been disrupted by genetic modification. Thus mice lacking production of the FSH beta subunit (Kumar et al. 1997) or lacking the FSH receptor (Dierich et al. 1998, Abel et al. 2000) retain a degree of fertility, whereas those in which the androgen receptor is knocked out are completely infertile (Yeh et al. 2002, De Gendt et al. 2004). This is true even when the knockout is restricted to Sertoli cells thus allowing other aspects of masculinization to occur (De Gendt et al. 2004).

Stimulatory actions of estrogens on testis development have been reported in a number of other rodent models and provide some evidence that estradiol exerts its stimulatory effects via an interaction with FSH. For example, treatment of neonatal rats with estradiol benzoate in the second week of life (postnatal days 5 to 11) stimulates mitosis such that the abundance of type A spermatogonia increases as assessed at day 15 (Kula 1988). In this same experimental paradigm, estradiol benzoate treatment significantly enhanced the actions of FSH on pre-meiotic differentiation at this early stage of development resulting in increased abundance of pachytene spermatocytes (Kula et al. 2001). Similar stimulatory effects of diethylstilbestrol treatment in the neonatal period on the initiation of spermatogenesis in rats have also been observed associated with small increases in circulating FSH (Atanassova et al. 2000). Thus, it is possible that estradiol is acting directly on immature pituitary gonadotropes to induce $\mathrm{FSH}$ secretion, even though one would normally expect estradiol to act as a negative feedback agent and inhibit FSH production in adult male rodents (Ebling et al. 2000). Perhaps the gonadotropes in the pituitary of the hpg mouse can be considered to be functionally immature as they have never been exposed to $\mathrm{GnRH}$, hence the pituitary gland in an 'adult' hpg mouse responds to estradiol in a similar way to that in the neonatal rat. In support of this conjecture that the gonadotropes of the hpg mice retain early developmental characteristics, it has recently been demonstrated that the expression of the melatonin (MT1) receptor is substantially higher in the pituitary gland of the hpg mouse than in age-matched litter mates (Johnston et al. 2003). A high level of expression of MT1 is a characteristic feature of the fetal-neonatal stage of pituitary gland development in rats and mice (Johnston et al. 2003), thus the maintenance of high levels of expression in the pituitary glands of 'adult' hpg mice suggests incomplete maturation of this tissue.

The induction of FSH secretion is clearly not the only mechanism by which estradiol promotes testicular function. For example, treatment of adult Siberian hamsters during the seasonal phase of testicular regression with low levels of estradiol can initiate the recrudescence phase, as observed by increased testis weight and histological analysis of germ cell line development (Pak et al. 2002). This estrogenic stimulation of seasonal testis reactivation correlates with decreased levels of pituitary and plasma $\mathrm{LH}$ and FSH compared with control hamsters treated with cholesterol (Pak et al. 2002), implying actions of estradiol within the testis that over-ride the decreased gonadotropin drive. Moreover, Kula et al. (2001) demonstrated that combined treatment of neonatal rats with both FSH and estradiol markedly enhanced the efficiency of premeiotic spermatogenesis, suggesting a synergistic effect probably at the level of the Sertoli cell.

The studies in which concurrent treatment with Faslodex blocked the actions of estradiol provide evidence that the stimulatory actions of estrogen are true actions via the known genomic receptors, and not, for example, crossreactivity of estrogen with androgen receptors, as has been proposed for estrogenic actions on the prostate gland (Yeh et al. 1998). Indeed, the concurrent anti-androgen treatment had no effect on estrogen-induced growth of the seminal vesicles and epididymides, whereas concurrent Faslodex treatment completely blocked this. We infer that there are direct actions of estradiol in these tissues, distinct from those mediated via the androgen receptor. Stimulatory actions of estradiol on prostate and seminal vesicle growth in the $h p g$ mouse have previously been reported (Bianco et al. 2002) and are consistent with the expression of ER $\alpha$ in stromal cells in these tissues (see Bianco et al. 2002 for review). 
In conclusion, the stimulation of FSH production by estradiol is not sufficient to explain the initiation of spermatogenesis by estradiol in hpg mice. Blocking the actions of estradiol by the anti-androgen Casodex demonstrates a requirement for functional androgen receptors for induction of testicular growth. In contrast, the stimulatory actions of estradiol on the seminal vesicles and epididymides, classically considered androgen-responsive organs, are likely to be direct effects via estrogen receptors expressed in those tissues. Testicular maturation is arrested at a pseudo-neonatal stage in the hpg mouse due to the chronic gonadotropin insufficiency, so the physiological relevance of these experimental observations is likely to be that estradiol is important in the initial development of the male reproductive axis.

\section{Acknowledgements}

This work was supported by an AstraZeneca Collaborative grant and by BBSRC committee studentships ( $\mathrm{H} \mathrm{B}$ and E C F). We thank Dr A F Parlow and the NIDDK for the provision of assay reagents for the $\mathrm{LH}$ and $\mathrm{FSH}$ radioimmunoassays (study 1). Casodex and Faslodex are trade marks of the AstraZeneca group of companies. The authors declare that there is no conflict of interest that would prejudice the impartiality this scientific work.

\section{References}

Abel MH, Wootton AN, Wilkins V, Huhtaniemi I, Knight PG \& Charlton HM 2000 The effect of a null mutation in the follicle-stimulating hormone receptor gene on mouse reproduction. Endocrinology 141 1795-1803.

Abney TO 1999 The potential roles of estrogens in regulating Leydig cell development and function: a review. Steroids 64 610-617.

Atanassova N, McKinnell C, Turner KJ, Walker MJ, Fisher S, Morley M, Millar RM, Groome NP \& Sharpe RM 2000 Comparative effects of neonatal exposure of male rats to potent and weak (environmental) estrogens on spermatogenesis at puberty and the relationship to adult testis size and fertility: evidence for stimulatory effects of low estrogen levels. Endocrinology 141 3898-3907.

Bianco JJ, Handelsman DJ, Pedersen JS \& Risbridger GP 2002 Direct response of the murine prostate gland and seminal vesicles to estradiol. Endocrinology 143 4922-4933.

Bourguiba S, Genissel C, Lambard S, Bouraima H \& Carreau S 2003 Regulation of aromatase gene expression in Leydig cells and germ cells. Journal of Steroid Biochemistry and Molecular Biology 86 $335-343$.

Bronson FH \& Vom Saal FS 1979 Control of the preovulatory release of luteinizing hormone by steroids in the mouse. Endocrinology 104 1247-1255.

Carreau S 2002 The testicular aromatase: from gene to physiological role. Reproductive Biology 2 5-12.

Cattanach BM, Iddon CA, Charlton HM, Chiappa SA \& Fink G 1977 Gonadotropin releasing hormone deficiency in a mutant mouse with hypogonadism. Nature $269338-340$.

Chandolia RK, Weinbauer GF, Simoni M, Behre HM \& Nieschlag E 1991a Comparative effects of the chronic administration of the non-steroidal antiandrogens flutamide and Casodex on the reproductive system of the adult male rat. Acta Endocrinologica 125 547-555.

Chandolia RK, Weinbauer GF, Behre HM \& Nieschlag E 1991b Evaluation of a peripherally selective antiandrogen (Casodex) as a tool for studying the relationship between testosterone and spermatogenesis in the rat. Journal of Steroid Biochemistry and Molecular Biology 38 367-375.

Charlton HM, Halpin DMG, Iddon C, Rosie R, Levy G, McDowell IFW, Megson A, Morris JF, Bramwell A, Speight A, Ward BJ, Broadhead J, Davey-Smith G \& Fink G 1983 The effects of daily administration of single and multiple injections of gonadotropinreleasing hormone on pituitary and gonadal function in the hypogonadal (hpg) mouse. Endocrinology 113 535-543.

De Gendt K, Swinnen JV, Saunders PTK, Schoonjans L, Dewerchin M, Devos A, Tan DK, Atanassova N, Claassens F, Lecureuil C, Heyns W, Cermeliet W, Guillou F, Sharpe RM \& Verhoeven G 2004 A Sertoli cell-selective knockout of the androgen receptor causes spermatogenic arrest in meiosis. PNAS 101 1327-1332.

Dierich A, Sairam MR, Monaco L, Fimia GM, Gansmuller A, LeMeur M \& Sassone-Corsi P 1998 Impairing follicle-stimulating hormone (FSH) signaling in vivo: targeted disruption of the FSH receptor leads to aberrant gametogenesis and hormonal imbalance. PNAS $9513612-13617$.

Durkee TJ, Mueller M \& Zinaman M 1998 Identification of estrogen receptor protein and messenger ribonucleic acid in human spermatozoa. American Journal of Obstetrics and Gynecology 178 1288-1297.

Ebling FJP, Brooks AN, Cronin AS, Ford H \& Kerr JB 2000 Estrogenic induction of spermatogenesis in the hypogonadal ( $h p g$ ) mouse. Endocrinology 141 2861-2869.

Eddy EM, Washburn TF, Bunch DO, Goulding EH, Gladen BC, Lubahn DB \& Korach KS 1996 Targeted disruption of the estrogen receptor gene in male mice causes alteration of spermatogenesis and infertility. Endocrinology 137 4796-4805.

Fink G, Sheward WJ \& Plant TM 1983 The hypogonadal mouse pituitary contains bioactive LH. Journal of Reproduction and Fertility $70277-280$.

Fisher JS, Millar MR, Majdic G, Saunders PTK, Fraser HM \& Sharpe RM 1997 Immunolocalisation of oestrogen receptor alpha (ER $\alpha)$ within the testis and excurrent ducts of the rat and marmoset monkey from perinatal life to adulthood. Journal of Endocrinology 153 485-495.

Free MJ \& Jaffe RA 1979 Collection of rete testis fluid from rats without previous efferent duct ligation. Biology of Reproduction 20 269-278.

Furr BJ, Valcaccia B, Curry B, Woodburn JR, Chesterton G \& Tucker H 1987 ICl 176,334: a novel non-steroidal, peripherally selective antiandrogen. Journal of Endocrinology 113 R7-R9.

Hess RA, Bunick D, Lee KH, Bahr J, Taylor JA, Korach KS \& Lubahn DB 1997 A role for oestrogens in the male reproductive system. Nature 390 509-512.

Howard CV \& Reed MG 1998 Unbiased Stereology. Three-Dimensional Measurement in Microscopy. Oxford: BIOS Scientific.

Johnston JD, Messager S, Ebling FJP, Williams LM, Barrett P \& Hazlerigg DG 2003 Gonadotrophin-releasing hormone drives melatonin receptor down-regulation in the developing pituitary gland. PNAS 100 2831-2835.

Johnston H, Baker PJ, Abel MH, Charlton HM, Jackson G, Fleming L, Kumar TR \& O'Shaughnessy PJ 2004 Regulation of Sertoli cell number and activity by follicle-stimulating hormone and androgen during postnatal development in the mouse. Endocrinology 145 318-329.

Krege JH, Hodgin JB, Couse JF, Enmark E, Warner M, Mahler JF, Sar M, Korach KS, Gustafsson JA \& Smithies O 1998 Generation and reproductive phenotypes of mice lacking estrogen receptor beta. PNAS 95 15677-15682.

Kula K 1988 Induction of precocious maturation of spermatogenesis in infant rats by human menopausal gonadotropin and inhibition by simultaneous administration of gonadotropins and testosterone. Endocrinology 122 34-39.

Kula K, Walczak-Jedrzejowska R, Slowikowska-Hilczer J \& Oszukowska E 2001 Estradiol enhances the stimulatory effect of FSH on 
testicular maturation and contributes to precocious initiation of spermatogenesis. Molecular and Cellular Endocrinology $\mathbf{1 7 8}$ 89-97.

Kumar TR, Wang Y, Lu N \& Matzuk MM 1997 Follicle stimulating hormone is required for ovarian follicle maturation but not male fertility. Nature Genetics 15 202-204.

Li X, Nokkala E, Yan W, Streng T, Saarinen N, Warri A, Huhtaniemi I, Santti R, Makela S \& Poutanen M 2001 Altered structure and function of reproductive organs in transgenic male mice overexpressing human aromatase. Endocrinology 142 2435-2442.

Luo A, Martela C, Chena C, Labriea C, Candasa B, Singha SM \& Labriea F 1997 Daily dosing with flutamide or Casodex exerts maximal antiandrogenic activity. Urology 50 913-919.

Mahato D, Goulding EH, Korach KS \& Eddy EM 2000 Spermatogenic cells do not require estrogen receptor alpha for development or function. Endocrinology 141 1273-1276.

Morton DB, Jennings M, Buckwell A, Ewbank R, Godfrey C, Holgate B, Inglis I, James R, Page C, Sharman I, Verschoyle R, Westall L \& Wilson AB 2001 Refining procedures for the administration of substances. Report of the BVAAWF/FRAME/RSPCA/UFAW Joint Working Group on Refinement. British Veterinary Association Animal Welfare Foundation/Fund for the Replacement of Animals in Medical Experiments/Royal Society for the Prevention of Cruelty to Animals/Universities Federation for Animal Welfare. Laboratory Animals $351-41$.

Murr SM, Geschwind II \& Bradford GE 1973 Plasma LH and FSH during different oestrous cycle conditions in mice. Journal of Reproduction and Fertility 32 221-230.

Nwagwu MO, Baines H \& Ebling FJP 2003 Western blot analysis of estrogen receptor alpha and beta in pituitary and testis of hypogonadal and wild-type mice. In Programme of the Annual Meeting of the British Society for Neuroendocrinology. Ed S Luckman. British Society for Neuroendocrinology: Manchester.

O'Donnell L, Robertson KM, Jones ME \& Simpson ER 2001 Estrogen and spermatogenesis. Endocrine Reviews 22 289-318.

Pak TR, Lynch GR \& Tsai PS 2002 Estrogen accelerates gonadal recrudescence in photo-regressed male Siberian hamsters. Endocrinology $1434131-4134$.

Pelletier G \& El-Alfy M 2000 Immunocytochemical localization of estrogen receptors alpha and beta in the human reproductive organs. Journal of Clinical Endocrinology and Metabolism 85 4835-4840.

van Pelt AMM, de Rooij DG, van der Burg B, van der Saag PT, Gustafsson JA \& Kuiper GGJM 1999 Ontogeny of estrogen receptor-beta expression in rat testis. Endocrinology 140 478-483.

Robertson KM, O'Donnell L, Jones MEE, Meachem SJ, Boon WC, Fisher CR, Graves KH, McLachlan RI \& Simpson ER 1999 Impairment of spermatogenesis in mice lacking a functional aromatase (cyp19) gene. PNAS 96 7986-7991.

Saunders PTK, Fisher JS, Sharpe RM \& Millar MR 1998 Expression of oestrogen receptor beta (ER $\beta)$ occurs in multiple cell types, including some germ cells, in the rat testis. Journal of Endocrinology $\mathbf{1 5 6}$ R13-R17.

Scott IS, Charlton HM, Cox BS, Grocock CA, Sheffield JW \& O'Shaughnessy PJ 1990 Effect of LH injections on testicular steroidogenesis, cholesterol P450scc mRNA content and Leydig cell morphology in hypogonadal mice. Journal of Endocrinology 125 $131-138$.

Sharpe RM, McKinnell C, Kivlin C \& Fisher JS 2003 Proliferation and functional maturation of Sertoli cells, and their relevance to disorders of testis function in adulthood. Reproduction 125 $769-784$

Sheffield JW \& O'Shaughnessy PJ 1989 Effect of injection of gonadotropin-releasing hormone on testicular steroidogenesis in the hypogonadal (hpg) mouse. Journal of Reproduction and Fertility $\mathbf{8 6}$ 609-617.

Singh J \& Handelsman DJ 1996 The effects of recombinant FSH on testosterone-induced spermatogenesis in gonadotrophin-deficient ( hpg) mice. Journal of Andrology 17 382-392.

Singh J, O'Neill C \& Handelsman DJ 1995 Induction of spermatogenesis by androgens in gonadotropin-deficient (hpg) mice. Endocrinology 1365311 - 5321.

Skarda J 2003 Bioassay of steroid hormone agonist and antagonist activities of anti-androgens on mammary gland, seminal vesicles and spleen of male mice. Journal of Veterinary Medicine $\mathbf{5 0}$ 204-212.

Stanley HF, Lyons V, Obonsawin MC, Bennie J, Carroll S, Roberts JL \& Fink G 1988 Regulation of pituitary alpha subunit, beta luteinizing hormone and prolaction mRNA by $\mathrm{GnRH}$ and estradiol in hypogonadal mice. Molecular Endocrinology $21302-1310$.

Verhoeven G \& Cailleau J 1990 Influence of coculture with Sertoli cells on steroidogenesis in immature rat Leydig cells. Molecular and Cellular Endocrinology 71 239-251.

Vom Saal FS, Timms BG, Montano MM, Palanza P, Thayer KA, Nagel SC, Dhar MD, Ganjam VK, Parmigiani S \& Welshons VVV 1997 Prostate enlargement in mice due to fetal exposure to low doses of estradiol or diethylstilbestrol and opposite effects at high doses. PNAS 94 2056-2061.

Wakeling AE \& Bowler J 1992 ICI 182, 780, a new antioestrogen with clinical potential. Journal of Steroid Biochemistry and Molecular Biology 43 173-177.

Weniger JP 1993 Estrogen production by fetal rat gonads. Journal of Steroid Biochemistry and Molecular Biology 44 459-462.

Yeh SY, Miyamoto H, Shima H \& Chang C 1998 From estrogen to androgen receptor: a new pathway for sex hormones in prostate. PNAS $955527-5532$.

Yeh S, Tsai MY, Xu Q, Mu XM, Lardy H, Huang KE, Lin H, Yeh SD, Altuwaijri S, Zhou X, Xing L, Boyce BF, Huang MC, Zhang S, Gan L \& Chang C 2002 Generation and characterization of androgen receptor knockout (ARKO) mice: an in vivo model for the study of androgen functions in selective tissues. PNAS 99 13498-13503.

Zhou Q, Nie R, Saunders PTK, Katzenellenbogen BS, Prins GS \& Hess RA 2002 Localization of androgen and estrogen receptors in adult male mouse reproductive tract. Journal of Andrology $\mathbf{2 3}$ 870-881.

Received 17 February 2005

First decision 22 April 2005

Revised manuscript received 25 July 2005

Accepted 2 August 2005 